udc 78:085.7(460)

doi 10.18485/bells.2015.7.9

\author{
Rossman Palfrey and Azamat A. Akbarov \\ International Burch University \\ Sarajevo, Bosnia and Herzegovina
}

\title{
THE EARLY SARABANDE AND CHACONNE: MEDIA LINGUA, STEREOTYPES, AND ETYMOLOGICAL SPECULATION RELATING TO AFRICAN DANCE AND LITERATURE IN COLONIAL AND IMPERIAL SPAIN
}

\begin{abstract}
The chaconne and sarabande, two dances that have flourished in Western Art Music since the sixteenth century, have frequently been assigned African or New World origins. In the twentieth century, there was a well-published debate regarding the origins of the chaconne and sarabande, two forms that first found favor in the sixteenth century as fast, raucous, and popular dances, but that left a lasting legacy as slow, refined court dances. This paper investigates this debate regarding the origins of the chaconne and sarabande, and uses examples from Spanish literature to examine authors' myriad claims and assumptions regarding the chaconne and sarabande. The result serves to place literary mentions of the chaconne and sarabande in the cultural context of colonial and imperial Spain. Specifically, the focus is on media lingua and parody in authors' portrayals of the "exotic" other, especially blacks and the peoples indigenous to the Spanish colonies. By compiling, analyzing, and critiquing the circumstances surrounding the histories of the chaconne and sarabande, this paper serves as both a historiography and a critique of previous histories.
\end{abstract}

Key words: sarabande, chaconne, media lingua, stereotypes, colonialism, imperialism, Spain. 


\section{Introduction}

In examining claims to the chaconne and sarabande's vulgarity, one gets a sense of the interaction among classes, nations, and ethnic groups. Early accounts reveal, at times, a disparaging view of the early chaconne and sarabande, wherein authors associate the dances with lower classes and vulgar behavior. This study puts a focus on the culture surrounding early sarabandes and chaconnes, and it brings to attention the way that social roles, social stigmas, and popular beliefs helped to influence the idea that these dances were both admired and shunned by Europeans in their earliest forms.

The following is an adaptation of these authors 2014 thesis for Northwestern University.

\section{History, Perception, and Stereotype}

The chaconne and sarabande have a curious history, one in which they move from disreputable to respected, slow to fast, gaudy to refined. Explanations of their beginnings differ but in American and English schools of thought a common narrative describing their origins and evolution might go something like this:

The zarabanda and chacona originated in the New World when European expatriates, savage natives, and their mixed offspring created fast-tempo, highly sexualized triple-meter dances which, in Spain and New Spain they called the zarabanda and chacona. These dances madetheir way to Europe, where they were censured by royal decrees and the Catholic Church, which ensured their lasting popularity. As the dances' popularity increased, royal courts began to incorporate the dances into their gatherings. The dances, for practical, social, and political reasons had to be toned down to please both the royals and religious authorities. Hence, composers created the slow and magnificent sarabandes and chaconnes of the High Baroque era.

It is a great story, one that stimulates the imagination: playing off the pauper to prince archetype, the imagined italicized history above suggests overcoming scandal, struggle, and taboos. Somehow, it would seem, the lowly zarabanda and chacona climbed the social ladder and became pinnacles of artistic achievement. They were welcomed in the highest 
courts of Europe, and musicians have continued to perform them into the twenty-first century. This story is, in modern dictionaries, encyclopedias, and popular imagination, the authoritative account.

According to the most recent edition of the Grove Dictionary of Music and Musicians, the sarabande was "one of the most popular of Baroque instrumental dances and a standard movement, along with the allemande, courante and gigue, of the suite. It originated during the 16th century as a sung dance in Latin America and Spain... The zarabanda was banned in Spain in 1583 for its extraordinary obscenity... From about 1580 to 1610 it seems to have been the most popular of the wild and energetic Spanish bailes, superseded finally by the chacona (see Chaconne), with which it is frequently mentioned" (Hudson \& Little 2015). The Grove dictionary describes the chaconne in similar terms, suggesting that it "appears to have originated in Spanish popular culture during the last years of the 16th century, most likely in the New World. No musical examples are extant from this period, but references by Cervantes, Lope de Vega, Quevedo and other writers indicate that the chacona was a dance-song associated with servants, slaves and Amerindians. It was often condemned for its suggestive movements and mocking texts..." (Silbiger 2015).

Though these accounts are compelling, closer investigation suggests a more nuanced history, one in which the geographical and cultural origins of the dances remain unclear, and in which their evolution from erotic to elegant demands further inquiry. The primary sources that propose the dances' origins are problematic. They are often contradictory, and they are rife with prejudice, suggesting a history that can seem more based on imagination than on fact. The following study interrogates the tantalizing tale of "a sexily swirling dance that appeared in South America at the end of the sixteenth century and quickly spread to Europe, becoming popular both in the elite courts and in the general population" (Ross 2014).

In order to best explain the origins and evolution of the chaconne and sarabande, one must delve into the history of not just the music, but of colonization, race-relations, and the culture of Western European society in the sixteenth through eighteenth centuries. Extra-European popularity seems to be a code suggesting unethical behavior, or at least for behavior that existed outside of cultural norms among white Europeans. Around the turn of the sixteenth century, among others, the esteemed Spanish authors Miguel de Cervantes (c. 1547-1616) and Lope de Vega (15621635) depict the dances in a satirical and critical manner. They and their 
contemporaries suggest multiple places of origin - sometimes in the New World, sometimes in Africa. The only "facts" about which the authors remain consistent are that the music was often played on the guitar, and its sexualized dances and controversial lyrics were enjoyed by lowest classes in European society, often by non-whites.

In New Spain, the area of Spanish colonization in the Americas, Spanish settlers enforced a caste system based on race, splitting people into two groups: gente de razón (Spanish whites) and gente sin razón (non-whites and aboriginal peoples) (Miranda 1988: 265). As the name suggests, the gente sin razón, were considered to have an inferior ability to make decisions regarding their spiritual futures, and music came to play an important role in attracting and converting Native Americans and African slaves. Descriptions abound of the non-Europeans' love for music and dance. In early European descriptions of Native American and African dances, colonists are scandalized by what they considered to be erotic or sinful movements. Particularly, they were disturbed by "wriggling" and movements of the upper body, which contrasted starkly with the way that European dancers kept their upper bodies comparatively motionless (Arbeau and Kendall 2013: 80). However, by the seventeenth century, church musicians throughout Europe and the New World appropriated musical and lyrical aspects of the chaconne and sarabande, using them in church services, even when celebrating holidays.

\section{Portrayal in Literature, use of Media Lingua}

In early mentions of the chaconne and sarabande, and in mentions of non-European dance dating back to the fifteenth century, Spanish authors typically have characters speaking in a pidgin language, the media lingua or half-language that slaves from diverse cultures used to communicate. As such, though Spanish was the true common language between diverse groups of people, it was the pidgin media lingua that actually served as their means of communication. Consistently, this media lingua, as well as the content of characters' conversations, satirizes the exotic other. The literature from the early seventeenth century onward, the chaconne and sarabande, well known to Spanish readers, serve to underscore European superiority. The exact origin of each dance remains ambiguous, and claims to extra-European origins seem more based on sixteenth century prejudice 
and modern misinterpretation than on historical fact. The use of the terms chacona and zarabanda in literary and musical texts generally conflate the two dances and condemn them. Moreover, as early as the fifteenth century, Spanish literary culture was saturated in references to non-Europeans wherein their cultures and preferences acted as symbols for savagery. In such literature, modern interpretations must be informed by knowledge of the prejudices so prevalent at the time.

In reading descriptions of the chaconne and sarabande, one senses the strong African presence in Spain and New Spain. As Spain developed as a unified nation, and thrived with the help of slaves and a booming slave trade, its authors developed a "distinct way of depicting blacks in Hispanic letters... the expulsion of the Moors and the Jews in 1492, the discovery of the New World, and most importantly the introduction of sub-Saharan African slaves in considerable numbers radicalized Spanish society and created an artistic climate hostile to blacks" (Mullen 1986: 235). Arguably, the expulsion of the Moors and Jews, the discovery (and exploitation) of the New World, and the influx of slaves and slave traders created a climate of xenophobia, that was judgmental not only of Africans, but of anything not European. Political, social, and economic factors created an "authoritative core of 'official texts' (in which) are a set of aesthetic norms which present White and Black as antithetical elements, each emblematic of opposites in the Castilian/Christian value system" (ibid: 235). Black or non-white didn't simply refer to a race, it referenced a variety of opposing dualities: vulgar vs. cultured, ignorant vs. knowledgeable, illiterate vs. literate, uninhibited vs. composed - all of these dualities were implied in the black vs. white dichotomy.

In the literary sources that reference the chaconne and sarabande, performers of these dances are consistently on the "black" end of these dualities. In order to properly interpret early references to the chaconne and sarabande, primary documents must be analyzed in the context of Spain's demeaning attitude towards the non-European peoples who they enslaved and marginalized, especially Native Americans and Africans. However, in the past, up through early twenty-first century, this contextualization has been largely neglected. The supposed extra-European origins of the chaconne and sarabande have been based largely on inference, possible misinterpretation, and etymological speculation. The exact origin of each dance remains ambiguous, and claims to extra-European origins seem more based on sixteenth century prejudice and modern misinterpretation 
than on historical fact. The ambiguity of their origins persists despite that fact that the terms chacona or ciacona, and zarabanda or sarabanda in sixteenth and seventeenth century sources continually associate the music with Africans and Native Americans.

In his Coplas, Around 1480, before the chaconne or sarabande have been mentioned in any known texts, before the discovery of the New World, Rodrigo de Reinosa presents a characterization of African slaves, and he does so in the form of a song. "The explicitly dramatic nature of the coplas is apparent from the indication they were intended to be sung to the tune of 'La niña, cuando bayleis'. The dialogue is interesting from several points of view. It is set in Seville, a center of the Spanish-African slave trade, and thus a center of Spanish-African slave culture. The protagonists (a black man, Jorge, and a black woman, Comba) speak in a comic pseudodialect, use profanity freely, and insult each other; each denigrates the other's country of origin and compares the relative status of their masters. The selection ends with an invitation by Jorge to dance and hacer choque choque, an obvious reference to sexual intercourse" (ibid: 237). Musically, Reinosa's poem is especially revealing because, if sung, his work would be strophic, repetitive, just like the early examples of chaconnes and sarabandes. Sociologically, Reinosa's poem shows that even before the discovery of the New World, and the golden age of the Spanish Empire, there already was a tradition of using dance to stereotype African slaves as having loose sexual morals.

Reinosa wrote his Coplas about fifty years before the earliest known mention of the chaconne or sarabande. Though Reinosa does not call his work a chaconne or sarabande, its overtly sexual lyrical content and its strophic form reflect the earliest examples of the chaconne and sarabande. Reinosa's poem is lyrically analogous to the chaconne and sarabande in that it is extolls intercourse, specifically using dance as an analogy for the act. Moreover, Reinosa depicts African slaves in much the same way that Cervantes would over one hundred years later, when describing the chaconne. In a moment of pure speculation, one might wonder whether or not the word chacona is in some way related to the onomatopoeia choque choque. Such speculation regarding the origins of the chaconne and sarabande abounds, yet there is little hard evidence supporting any of the various etymological explanations of the dance's origins.

In the mid-to-late twentieth century, musicologists Robert Stevenson and Daniel Devoto engaged in a well-documented debate during which, in 
multiple journals, Stevenson argued for New World origins of the sarabande and Devoto argued for European origins (Stevenson, Devoto and Escudero 1961: 113). In their debate, they collected, refuted, and supported a wide variety of accounts of the origins of the sarabande. Given the variation in accounts of the early chaconne and sarabande, It may well be that one or some of Stevenson's and Devoto's explanations for the names of the chaconne and sarabande contain some truth. However, lacking additional evidence, it is difficult to pinpoint a single explanation that seems any more believable than another.

In examining some of the earliest known references to the chacona and zarabanda, in the works of Lope de Vega, and Miguel de Cervantes one develops a sense that the dances are generally depicted in a critical or satirical manner (Hudson \& Little 2015). Cervantes regularly condemns the chacona and sarabanda and relates them to the exotic performers in his Novelas Ejemplare. Luis, an African slave in El celoso extremeño, a novela in Cervantes' Novelas Ejemplares (1613), can do nothing but strum the guitar "blissfully unaware that his guitar is out of tune and lacking several strings" (Hall 1978: 362). Luis is a slave of the pseudo-aristocrat Filipo de Carrizales, who made his fortune in the New World (Cervantes 1613). Cervantes further exaggerates the effects of the zarabanda on Africans when Luis's guitar teacher "enthralls [the other slaves]... with the demoniacal strains of the zarabanda" (Hall 1978: 362). Cervantes, in addition to humorously depicting black characters, claims "es la inclinación que los negros tienen a ser músicos" (Cervantes 1613). Eventually the guitar teacher himself is forced to New Spain, where the "demoniacal strains of the zarabanda" presumably belong. Herein, Cervantes suggests extra- European popularity, especially among people of African and/or New World origin.

Again, allusions to the chaconne and sarabande abound in La ilustre fregona, another novella from Cervantes' Novelas emplejares. The character Lope attempts to seduce the great beauty Costancica by performing a chaconne (Cervantes 1613). Lope, a talented musician of low status, brags of skill not just in the chacona, but in the folias and sarabande, as well. In this chaconne, Lope sings of the "alegre zarabanda" which " entrarse por los resquicios de las casas religiosas" and he refers to the chaconne and sarabande as "extranjero... una 'indiana amulatada" (Cervantes 1613). Lope's serenade is also joined by dancers, and in the song itself Lope states that properly dance it people "requieran las castañetas", instrument/props that the baroque Maître de Danse Raoul Auger Feuillet later associates 
with exoticism, especially Spanish exoticism (Feuillet and Pécourt 1968: 102). Thusly, Cervantes continues to exoticize and create caricatures in his depictions of the chaconne and sarabande. Given the extremely satirical, even racist, nature of such texts, these literary explanations of the music's origins are dubious at best. The music is assigned such origins perhaps not to explicate its beginnings, but to explicate the obscenity with which it was often associated.

\section{Etymological Explanations}

In early and recent claims to New World origins of the chacona and zarabanda, doubts abound. Besides the vaguely and/or overtly racist claims to New World origins, there exist a number of etymological claims to extra-European origins. For example, the zarabanda has been explained as "oriental... since the Spanish name for the dance, zarabanda, sounds like the Persian sar-band", and tenuous explanations for the origins of the chacona date back to the 1600's (Stevenson 1952: 29). The chacona has been described, at turns, as Mexican, African, Spanish, Italian, and Portuguese in origin (Hudson 1982: xii). Each of these explanations of origin relies on etymological evidence, rather than evidence preserved in any kind of musical notation. In 1622, Pedro Arias Peìrez "offers a fascinating - if suspect - derivation of the word itself: 'estatierra, amigos mios/ es la isla de Chacona/ Porotro nombre cucanba"' (Walker 1968: 303) In their pronunciation, the words Chacona and Cucanba do seem tangentially related, but beyond this, the allusion to the chacona might not be to suggest its origins; instead it could evoke the hedonistic pleasures with which the chacona was associated. It would seem that "the image of a remote land where the good life is to be found is indeed not far removed from the much older legend of Cucania (ibid: 303). As such, it seems doubtful that the chacona is actually related to the island. Alternate explanations include: the chacona was originated by a blind Italian (F. Alfonso Ciacona), chacona is an onomatopoeia referring to the sound of castanets (chac), chacona refers to the Native Americans of Chaco... the list goes on (Hudson 1982: 5-6). Given the wide variety of and disparity between explanations, these etymological suggestions do little to pinpoint the exact origins of the chaconne. 
Even when disregarding explanations of Middle Eastern origins, the zarabanda suffers a similarly convoluted historiography. Nonetheless, it is still accepted by many respected music historians as having its origins in the New World. Musicologists have proclaimed a preponderance of evidence suggesting that the dances have Mexican origins. Among these early sources, Peter J. Burkholder appears to reference Stevenson's older proclamation of a "description by New World missionary Diego Duraìn in his 1579 Historia de las Indias de Nueva Espanba, [which] compares a 'brisk and saucy' dance of the Aztec Indians to 'that sarabande which our own people dance' (esta zarabanda que nuestros naturales usan), referring to people born in Mexico of Spanish descent," when he endorses the suggestion that "the sarabande "was imported from Mexico"' (Burkholder 2009: 402). Burkholder refers to other sources as well, and they all suffer the same problem; none are musical texts. Indeed the Diego Durain text (which is borrowed from an earlier article by Robert Stevenson) is in itself suspect, as it seems suggest the exact opposite of what he, or rather Stevenson, claims. Taken in context, Diego Duraìn uses the zarabanda to describe a lascivious Spanish dance that is similar in its motions to a different dance, the cuecuecheuycatl, an Aztec dance. The zarabanda serves as a reference point, so that Spanish readers can understand the sinful Aztec dance that Duraìn is condemning (Esses 1992: 701). Note that Duran is Spanish, not Aztec, so clearly the dance of his own people would not be Aztec.

Stevenson additionally argues that the zarabanda, even if it is not of Native American origin, is likely have originated in the New World because, in Europe, the "first dated description of the dance itself [is of] the sarabande danced in Barcelona (Platter and Finn 1839)". In the New World, both descriptions of the dance itself and texts to zarabandas predate this European description by decades. However, by 1599, European descriptions of the zarabanda are nearly always linked to the chacona, and the chacona is described as being so vulgar that it displaced the zarabanda's popularity: "The zarabanda had already been singled out for castigation. In 1599 for the first time, although by no means the last, the chacona was included" (Walker 1968: 301). By the early 1600's, Lope de Vega describes the zarabanda as "muy vieja" (very old), and Covarrubias defines the "cąrabanda [sic]. A bayle which would be well known in these times, if its cousin the chacona had not deprived it of its popularity" (Esses 1992: 701). Such descriptions suggest that the zarabanda was not new to Europe at all, 
but was beginning to go out of fashion by the time it is first described in such literature.

\section{Conclusion}

Given a lack of any New World or African musical sources describing the chaconne and sarabande, the evidence for extra-European origins can seem like suspicious hearsay. Discussions of exotic origins read more like a coding for dances "characterized by erotic movements" (Esses 1992: 739). The implicit savagery and exoticism of the New World served to underscore the fact that these dances were "associated almost exclusively with the lower classes" (Esses 1992: 740).

Though inferences from literature and etymological speculation give a mixed picture of the chaconne and sarabande's origins, the exact origins of the dances are peripheral to their continued influence in European music. Even if the dances are indeed European, rather than from the New World, the use of language in the literature surrounding their history implicitly elucidates Western European, especially Spanish, perception of race in the sixteenth through eighteenth century. In reproducing early chaconnes and sarabandes, performers would do well to note that it was their lyrical content and racy choreography that earned the chaconne and sarabande their well-documented notoriety. Though musically standard, their reputations present a plethora of European prejudices, wherein white Europeans presented racial classifications that defied the sensibilities of indigenous peoples outside of Europe. "Just as black was a broad categorization presenting most Africans as "other," the term "Indian' is, after all, a European invention, a sweeping cultural and ethnic category unimagined by the people it named, serving to distinguish colonized from self-righteous colonizer, both morally and politically, and to define legal rights and duties" (Katzew 2011: 15).

Ultimately it doesn't seem to matter much whether the chaconne and sarabande originated in Europe or elsewhere, for their exotic reputation prevailed even after court musicians appropriated them for purposes far removed from their original, popular, bawdy origins. Rather than assuming a non-European origin, considering their European roots can make for a more nuanced history. While their geographical place of origin cannot be proven, their synthesis of European and non-European cultures, their 
subversive texts, and their important role throughout Europe and the New World demonstrate the diverse cultural milieu that existed when these dances first found popularity. The history of the chaconne and sarabande requires literary critics, performers, listeners, and historians alike to engage their imaginations, to use the dances and the language surrounding them to envision the complex relationships among a diverse array of peoples and cultures in continental Europe and its colonies.

\section{References}

Arbeau, T. and G.Y. Kendall, (2013). The Music of Arbeau's Orchesographie [1598]. New York: Pendragon Press.

Arbeau, T. (1967). Orchesography [1598]. New York: Dover Publications. Burkholder, J. P. (2009). Music of the Americas and Historical Narratives. American Music, 27, 4, 399-423.

Cervantes Saavedra, Miguel de, Florencio Sevilla Arroyo, and Antonio Rey Hazas (1991). La ilustre fregona, Novelas ejemplares. Madrid: Espasa Calpe. 24-27/291-294 (14 May 2015). <http://biblio3.url.edu.gt/ Libros/2011/novelas.pdf $>$.

Devoto, D. (1964). Encore sur "la" sarabande. Revue De Musicologie, 50, 129, 175-207.

Devoto, D. (1960). La folle Sarabande. Revue De Musicologie, 45, 121, 3-43.

Devoto, D. (1960a). La folle Sarabande (II). Revue De Musicologie, 46, 122, 145-180.

Esses, M. (1992). Dance and instrumental diferencias in Spain during the 17th and early 18th centuries. Stuyvesant, NY: Pendragon Press.

Feuillet, R.-A. and Pécourt, G. L. (1968). Chorégraphie, ou, L'art de décrire la dance: A facsimile of the 1700 Paris edition [1700]. New York: Broude Bros.

Hall, M. (1978). The 'Guitarra Espanbola' of Joan Carles Amat. Early Music, 6, 3, 362-373.

Hudson, Richard and Meredith Ellis Little."Sarabande."Grove Music Online.Oxford Music Online. Oxford University Press. (8 May 2015) $<$ http://www.oxfordmusiconline.com/subscriber/article/grove/ music/24574>. 
Hudson, R. (1982). The folia, the saraband, the passacaglia, and the chaconne: The historical evolution of four forms that originated in music for the fivecourse Spanish guitar. S.1.: American Institute of Musicology.

Katzew, I. (2004). Casta painting: Images of race in eighteenth-century Mexico. New Haven: Yale University Press.

Katzew, I., Alcalaì, L. E., Los Angeles County Museum of Art., \&Museo Nacional de Antropologila (Mexico) (2011). Contested visions in the Spanish colonial world. Los Angeles: Los Angeles County Museum of Art.

Mann, K. D. (2009). Indians, Song, and Dance in the Missions of Northern New Spain. (20 October 2014) < http://www.cilam.ucr.edu/diagonal/ issues/2009/Mann.pdf>

Miranda, G. E. (1988). Racial and Cultural Dimensions of "Gente de Razoìn" Status in Spanish and Mexican California. Southern California Quarterly, 70, 3, 265-278.

Mullen, E. J. (1986). Simoìn Aguado's “Entremeìs de los negros: Text and Context. Comparative Drama, 20, 3, 231-246.

Platter, Thomas the Younger, translated by the translator of Lavater's original maxims, Mrs. Finn. (1839). The Autobiography of Thomas Platter: A Schoolmaster of the Sixteenth Century [1599]. London: B. Wertheim.

Reinosa, R. and L. Puerto Moro (2010). Obra conocida de Rodrigo de Reinosa. San Millán de la Cogolla: CiLengua.

Ross, A. (2014) Listen to This (14 May 2015). < http://www.therestisnoise. $\mathrm{com} / \mathrm{chacona} />$.

Silbiger, A. (2015). Chaconne. Grove Music Online.Oxford Music Online. Oxford University Press. (14 May 2015).

<http://www.oxfordmusiconline.com/subscriber/article/grove/ music/05354>.

Stevenson, R. (1952) The First Dated Mention of the Sarabande. Journal of the American Musicological Society 5, 1, 29-31.

Stevenson, R., Devoto, D., \& Escudero, J. C. (1961). A Propos de la Sarabande. Revue De Musicologie, 47, 123, 113-125.

Walker, T. (1968). Ciaccona and Passacaglia: Remarks on Their Origin and Early History. Journal of the American Musicological Society, 21, 3, 300-320.

Received: 28 May, 2015

Accepted for publication: 10 Jun, 2015 
Rossman Palfrey and Azamat Akbarov: The Early Sarabande and Chaconne...

Розман Полфри и Азамат Акбаров

\author{
РАНА ТРАДИЦИЈА САРАБАНДЕ И ШАНСОНЕ: MEDIA LINGUA, \\ СТЕРЕОТИПИ И ЕТИМОЛОШКЕ РАСПРАВЕ У ВЕЗИ СА АФРИЧКОМ ИГРОМ \\ И КЊИЖЕВНОШЋУ У ШПАНИЈИ У КОЛОНИЈАЛНОМ И \\ ИМПЕРИЈАЛНОМ ДОБУ
}

\begin{abstract}
Сажетак
Рана традиција игара „Сарабанде“ и „Шансоне“ која је цветала у оквиру западне уметничке музичке традиције од шеснаестог века, често је имала порекло у играма из Африке и Новог света. У двадесетом веку, много је написано о пореклу шансоне и сарабанде које су широко прихваћене још у шеснаестом веку као брзе и окретне народне игре, а затим као такве утицале на стварање дворске плесне традиције лаганог и отменог плеса. У овом есеју пратиће се расправа о пореклу шансоне и сарабанде на основу примера из шпанске књижевности. Сврха истраживања је смештање шансоне и сарабанде у културни контекст колонијалне и империјалне Шпаније. Истраживање је посебно усмерено на media lingua истичући иронијску ноту са којом аутори говоре о егзотичном другом - групи људи са различитом бојом коже од расе колонизатора у шпанским колонијама. У овом есеју бавимо се набрајањем, анализирањем и вредновањем прилика у којима су настале шансона и сарабанде са циљем да дамо допринос тачности историографских и културолошких записа на основу критике постојећих историјских нарација.
\end{abstract}

Кључне речи: сарабанде, шансона, media lingua, стереотипи, колонијализам, империјализам, Шпанија. 